\title{
PERBEDAAN PENGETAHUAN IBU TENTANG AUTISME PADA BALITA USIA 3-4 TAHUN SEBELUM DAN SESUDAH DIBERI PENYULUHAN \\ Oleh :
}

Aprilia Nurtika Sari ${ }^{1}$, Alfi Firmareta ${ }^{2}$

Akademi Kebidanan Dharma Husada Kediri Jawa Timur

\begin{abstract}
ABTRAK
Autisme merupakan gangguan perkembangan anak yang sangat kompleks.Autime ditandai dengan tiga gangguan pada interaksi sosial, perilaku dan komunikasi.Autisme merupakan suatu sindrom yang mengganggu syaraf. Tujuan penelitian ini adalah untuk mengetahui perbedaan pengetahuan ibu yang memiliki balita usia 3-4 tahun tentang autisme sebelum dan sesudah diberikan penyuluhan.

Desain penelitian ini menggunakanpra-eksperimental dengan pendekatan one group pra-post test design. Populasi pada penelitian ini berjumlah $30 \mathrm{ibu}$ yang memiliki balita usia 3-4 tahun di Posyandu Kenanga dan Anggrek Desa Jambean, Kec. Kras, Kab. Kediri dengan teknik total sampling didapatkan 30 responden.Penelitian ini dilakukan pada tanggal 13 Mei sampai 16 Mei 2016. Variabel dalam penelitian ini yaitu variabel independen (penyuluhan tentang autisme) dan variabel dependen (pengetahuan ibu tentang autisme).Instrumen dalam penelitian ini menggunakan kuesioner.Data diolah dengan editing, coding, scoring dan tabulating kemudian data dianalisis menggunakan uji Wilcoxon.

Hasil penelitian menunjukkan dari 30 responden pengetahuan sebelum dilakukan penyuluhan dalam kategori cukup sebanyak 15 responden (50\%). Setelah diberikan penyuluhan dalam kategori baik sebanyak 26 responden $(86,67 \%)$. Berdasarkan hasil uji statistik menggunakan uji Wilcoxon diperoleh $Z_{\text {hitung }}$ sebesar $-4,792$ dengan nilai signifikasi $(\alpha)$ sebesar $0,000(\alpha \leq 0,05)$. Karena $\alpha \leq 0,05$ maka $\mathrm{H}_{1}$ diterima artinya ada perbedaan pengetahuan ibu tentang autisme pada balita usia 3-4 tahun sebelum dan sesudah diberikan penyuluhan.

Berdasarkan penelitian tersebut pengetahuan ibu tentang autismeakan lebih baik bila petugas kesehatan sering memberikan penyuluhan. Oleh karena itu, penyuluhan berperan penting dalam meningkatkan pengetahuan.
\end{abstract}

Kata Kunci : Pengetahuan, Autisme, Penyuluhan 
Aprilia Nurtika Sari;Perbedaan Pengetahuan Ibu tentang Autisme Pada Balita Usia 3-4

Tahun Sebelum dan Sesudah diberi Penyuluhan

\section{PENDAHULUAN}

Autisme merupakan gangguan perkembangan anak yang sangat kompleks. Disisi lain jumlah penderita gangguan autisme yang semakin banyak sehingga membuat para orang tua kini mulai memperhatikan dengan lebih serius perkembangan anaknya di usia yang sangat dini.

Istilah "autistik" diambil dari bahasa Yunani "autos" yang artinya self istilah ini digunakan untuk menjelaskan seseorang yang bersibuk diri dengan dunianya sehingga kelihatannya tidak tertarik pada orang lain. Dulu, anak-anak autis diduga punya ibu yang tidak hangat dan kurang memberikan kasih sayang.Tetapi sekarang sudah terbukti bahwa gangguan autisme adalah gangguan pada otak yang menyebabkan terhambatnya perkembangan dalam berbagai bidang. (Adriana, $2008: 23$ )

Munculnya ciri-ciri autistik pada setiap anak berbeda karena kompleksnya gangguan perkembangan ini.Sebagian anak punya banyak ciri yang kelihatan nyata, sementara yang lainnya menunjukkan beberapa ciri yang tidak terlalu kentara. Sebagian anak membutuhkan penanganan individual dan tetap tergantung pada orang lain sampai dewasa, sementara yang lainnya bisa belajar di sekolah umum dan mampu mandiri. Karena itulah akhir-akhir ini lebih sering digunakan istilah "Spektrum Autistik" untuk menunjukkan bahwa gangguannya memiliki rentang luas, dapat muncul secara berbeda pada setiap anak. (Adriana, $2008: 23-24$ )

Untuk dapat memberikan penanganan yang terbaik dan sesuai dengan kondisi individual anak, sebagai orang tua perlu mempersiapkan tenaga, pikiran, dan biaya yang tidak sedikit. Belum lagi dituntut pula penyesuaian dari anggota keluarga lain untuk dapat menciptakan interaksi harmonis dengan anak yang istimewa. (Adriana, 2008 : 9)

Salah satu kegiatan dalam posyandu adalah pemantauan tumbuh kembang anak berdasarkan SDIDTK ,dalam pedoman pelaksanaan SDIDTK terdapat skrining deteksi dini autis pada anak balita atau prasekolah yang disebut dengan CHAT (checklist for autism in toddlers).

Peran orang tua sangat penting dalam perkembangan anaknya, terutama bila terjadi penyimpangan perkembangan pada anak. Orang tua terutama ibu harus paham tentang apa saja yang terjadi pada anaknya terutama bila terjadi penyimpangan pada perkembangan. Pengetahuan ibu tentang penyimpangan perkembangan harus mencukupi karena peran ibu sangat dominan dalam merawat anaknya, walaupun ibu bekerja namun tetap peran seorang ibu lebih dominan dalam merawat anaknya.Namun pengetahuan orang tua terutama ibu masih minim tentang penyimpangan perkembangan anak terutama pengetahuan tentang autis.Hal ini dapat menyebabkan keterlambatan penanganan yang harus diberikan karena orang tua terlambat menyadari bahwa terjadi penyimpangan pada perkembangan anaknya.

Autisme terjadi pada 5 dari setiap 10.000 kelahiran dengan jumlah penderita laki-laki empat kali lebih besar dibandingkan dengan penderita perempuan. Namun demikian, jika perempuan yang menderitanya, penderitanya akan lebih parah dibandingkan dengan laki-laki.

(Wiyani, 2015 : 187)

Dari hasil studi pendahuluan yang dilakukan dengan wawancara di Posyandu Desa Jambean, Kec. Kras, 
Kab. Kediri pada tanggal 11 Mei 2016 didapatkan $10 \mathrm{ibu}$ yang memiliki anak usia 3-4 tahun. Diantara $10 \mathrm{ibu}$ tersebut terdapat $3(30 \%)$ ibu yang memiliki pengetahuan cukup tentang autisme dan $7 \quad(70 \%)$ ibu lainnya berpengetahuan kurang tentang autisme.Yang berarti hanya 30\% ibu yang berpengetahuan cukup tentang autisme dari 10 responden yang didapatkan.

\section{METODE}

Rancangan pada penelitian ini adalah rancangan penelitian pra eksperimental, dengan kategori pendekatan pra pasca tes dalam satu kelompok (One-group pra-post test design). Hal ini sesuai dengan tujuan penelitian yaitu untuk menguji perbedaan antara dua variabel. Penelitian ini dilakukan dengan cara memberikan pretest atau pengamatan awal terlebih dahulu mengenai pengetahuan tentang autisme sebelum diberikan intervensi, setelah itu diberikan intervensi, kemudian dilakukan post test atau pengamatan akhir mengenai pengetahuan tentang autisme. Populasi dalam penelitian ini adalah semua ibu yang memiliki balita usia 3-4 tahun di Posyandu Kenanga dan Anggrek Desa Jambean, Kec. Kras, Kab. Kediri yang terdiri dari 30 responden.Sampel dalam penelitian ini adalah semua ibu yang memiliki balita usia 3-4 tahun di Posyandu Kenanga dan Anggrek Desa Jambean, Kec. Kras, Kab. Kediri yang terdiri dari 30 responden. Dalam penelitian ini peneliti menggunakan teknik Total Sampling atau sampling jenuh, yaitu pengambilan sampel dengan cara memilih semua jumlah populasi yang ada dijadikan sampel. Pada penelitian ini variabel bebasnya adalah penyuluhan tentang autisme.Pada penelitian ini variabel terikatnyaadalah pengetahuan ibu tentang autisme.Dalam penelitian ini peneliti menggunakan Satuan Acara Penyuluhan (SAP), leaflet dan kuesioner, Instrumen yang digunakan pada penelitian ini adalah kuesioner.

\section{HASIL}

\section{Data Umum}

a. Karakteristik Responden Berdasarkan Umur

Tabel 1 Karakteristik Ibu Berdasarkan Umur Di Posyandu Kenanga dan Anggrek Desa Jambean, Kec. Kras, Kab. Kediri.

\begin{tabular}{ccccc} 
No & & Umur (Tahun) & Frekuensi & Prosentase (\%) \\
\hline 1 & $20-25$ & & 3 & 10 \\
\hline 2 & $26-30$ & 7 & 23,33 \\
\hline 3 & $31-40$ & & 18 & 60 \\
\hline 4 & $>40$ & & 2 & 6,67 \\
\hline & & Total & $\mathbf{3 0}$ & $\mathbf{1 0 0}$
\end{tabular}

Berdasarkan tabel 1 menunjukkan mayoritas responden berusia 31-40 tahun dengan jumlah responden sebanyak 18 orang $(60 \%)$ dan minoritas berusia $>40$ tahun dengan jumlah responden 2 orang $(6,67 \%)$. 
b. Karakteristik Responden Berdasarkan Pendidikan

Tabel 2 Karakteristik Ibu Berdasarkan Pendidikan Di Posyandu Kenanga dan Anggrek Desa Jambean, Kec. Kras, Kab. Kediri.

\begin{tabular}{clcc} 
No & \multicolumn{1}{c}{ Pendidikan } & Frekuensi & Prosentase (\%) \\
\hline 1 & Tidak Tamat SD & 0 & 0 \\
\hline 2 & SD/Sederajat & 1 & 3,33 \\
\hline 3 & SMP/Sederajat & 14 & 46,67 \\
\hline 4 & SMA/Sederajat & 13 & 43,33 \\
\hline 5 & Akademi/Perguruan Tinggi & 2 & 6,67 \\
\hline & Total & $\mathbf{3 0}$ & $\mathbf{1 0 0}$
\end{tabular}

Berdasarkan tabel 2 menunjukkan mayoritas responden berpendidikan hanya sampai SMP dengan jumlah responden 14 orang (46,67 dan hanya 1 orang $(3,33 \%)$ yang berpendidikan hanya sampai SD.

c. Karakteristik Responden Berdasarkan Pekerjaan.

Tabel 3 Karakteristik Ibu Berdasarkan Pekerjaan Di Posyandu Kenanga dan Anggrek Desa Jambean, Kec. Kras, Kab. Kediri.

\begin{tabular}{clcc} 
No. & Pekerjaan & Frekuensi & Prosentase (\%) \\
\hline 1 & Ibu Rumah Tangga & 27 & 90,01 \\
\hline 2 & Tani & 0 & 0 \\
\hline 3 & Swasta & 1 & 3,33 \\
\hline 4 & Wiraswasta & 1 & 3,33 \\
\hline 5 & Pegawai Negeri Sipil & 1 & 3,33 \\
\hline & Total & $\mathbf{3 0}$ & $\mathbf{1 0 0}$
\end{tabular}

Berdasarkan tabel 3 menunjukkan bahwa mayoritas pekerjaan ibu adalah Ibu Rumah Tangga (IRT) dengan jumlah responden 27 orang (90,01\%). Sedangkan pada pekerjaan swasta 1 orang $(3,33 \%)$, pada wiraswasta 1 orang $(3,33 \%)$ dan PNS 1 orang $(3,33 \%)$.

d. Karakteristik Responden Berdasarkan Jumlah Anak

Tabel 4 Karakteristik Ibu Berdasarkan Jumlah Anak Di Posyandu Kenanga dan Anggrek Desa Jambean, Kec. Kras, Kab. Kediri

\begin{tabular}{cccc} 
No & Jumlah Anak & Frekuensi & Prosentase (\%) \\
\hline 1 & 1 & 11 & 36,67 \\
\hline 2 & 2 & 14 & 46,67 \\
\hline 3 & 3 & 5 & 16,66 \\
\hline 4 & $>3$ & 0 & 0 \\
\hline & Total & $\mathbf{3 0}$ & $\mathbf{1 0 0}$
\end{tabular}

Berdasarkan tabel 4 menunjukkan mayoritas ibu memiliki jumlah anak 2 sebanyak 14 orang $(46,67 \%)$ dan minoritas ibu memiliki anak dengan jumlah 3 anak sebanyak 5 orang $(16,66 \%)$. 
e. Karakteristik Responden Berdasarkan Pernah atau Tidaknya Mendapatkan Informasi Tentang Autisme.

Tabel 5 Karakteristik Ibu Berdasarkan Pernah atau Tidak Mendapatkan Informasi Di Posyandu Kenanga dan Anggrek Desa Jambean, Kec. Kras, Kab. Kediri.

\begin{tabular}{clccc} 
No & & Informasi & Frekuensi & Prosentase (\%) \\
\hline 1 & Pernah & 6 & 20 \\
\hline 2 & Tidak Pernah & 24 & 80 \\
\hline \multicolumn{2}{c}{ Total } & $\mathbf{3 0}$ & $\mathbf{1 0 0}$
\end{tabular}

Berdasarkan tabel 5 menunjukkan informasi tentang autisme pada ibu prosentase tertinggi adalah tidak pernah dengan jumlah responden 24 orang $(80 \%)$ dan 6 orang $(20 \%)$ sudah pernah mendapat informasi tentang autisme.

f. Karakteristik Responden Berdasarkan Sumber Informasi.

Tabel 6 Karakteristik Ibu Berdasarkan Sumber Informasi Di Posyandu Kenanga dan Anggrek Desa Jambean, Kec. Kras, Kab. Kediri.

\begin{tabular}{clcc} 
No & Sumber Informasi & Frekuensi & Prosentase (\%) \\
\hline 1 & Petugas Kesehatan & 5 & 16,67 \\
\hline 2 & Keluarga & 0 & 0 \\
\hline 3 & Tetangga & 1 & 3,33 \\
\hline 4 & Media masa/elektronik & 0 & 0 \\
\hline & Total & $\mathbf{6}$ & $\mathbf{2 0}$
\end{tabular}

Berdasarkan tabel 6 menunjukkan dari 6 orang yang sudah pernah mendapat informasi tentang autisme, 5 orang $(16,67 \%)$ mendapatkan informasi dari petugas kesehatan sedangkan 1 orang $(3,33 \%)$ mendapatkan informasi dari tetangga.

2. Data Khusus

a. Pengetahuan Ibu Tentang Autisme Pada Balita Usia 3-4 Tahun Sebelum Diberi Penyuluhan (Di Posyandu Kenanga dan Anggrek Desa Jambean, Kec. Kras, Kab. Kediri)

Tabel 7 Pengetahuan Ibu Tentang Autisme Pada Balita Usia 3-4 Tahun Sebelum Diberi Penyuluhan (Di Posyandu Kenanga dan Anggrek Desa Jambean, Kec. Kras, Kab. Kediri)

\begin{tabular}{lccc}
\multicolumn{1}{c}{ Kriteria Pengetahuan } & Jumlah & Prosentase \% \\
\hline Kurang & 14 & 46,67 \\
\hline Cukup & 15 & 50 \\
\hline Baik & Total & 1 & 3,33 \\
\hline \multicolumn{2}{r}{} & $\mathbf{3 0}$ & $\mathbf{1 0 0}$
\end{tabular}

Berdasarkan tabel 7 menunjukkan bahwa dari 30 responden sebagian besar yaitu sebanyak 15 orang (50\%) mempunyai pengetahuan dengan kriteria cukup tentang autisme. 
b. Pengetahuan Ibu Tentang Autisme Pada Balita Usia 3-4 Tahun Sesudah Diberi Penyuluhan (Di Posyandu Kenanga dan Anggrek Desa Jambean, Kec. Kras, Kab. Kediri.

Tabel 8 Pengetahuan Ibu Tentang Autisme Pada Balita Usia 3-4 Tahun Sesudah Diberi Penyuluhan (Di Posyandu Kenanga dan Anggrek Desa Jambean, Kec. Kras, Kab. Kediri)

\begin{tabular}{|c|c|c|}
\hline Kriteria Pengetahuan & Jumlah & $\%$ \\
\hline Kurang & 0 & 0 \\
\hline Cukup & 4 & 13,33 \\
\hline Baik & 26 & 86,67 \\
\hline Total & 30 & 100 \\
\hline
\end{tabular}

Berdasarkan tabel 8 menunjukkan bahwa dari 30 responden yang diberi penyuluhan tentang autisme sebagian besar yaitu dengan jumlah responden 26 orang $(86,67 \%)$ memiliki pengetahuan dengan kriteria baik tentang autisme.

c. Tabel Silang Pengetahuan Ibu Tentang Autisme Pada Balita Usia 3-4 Tahun Sebelum Dan Sesudah Diberi Penyuluhan (Di Posyandu Kenanga dan Anggrek Desa Jambean, Kec. Kras, Kab. Kediri)

Tabel 9 Tabel Silang Pengetahuan Ibu Tentang Autisme Pada Balita Usia 3-4 Tahun Sebelum Dan Sesudah Diberi Penyuluhan (Di Posyandu Kenanga dan Anggrek Desa Jambean, Kec. Kras, Kab. Kediri)

\begin{tabular}{lcccc}
\multirow{2}{*}{$\begin{array}{c}\text { Kriteria } \\
\text { Pengetahuan }\end{array}$} & \multicolumn{2}{c}{ Sebelum Penyuluhan } & \multicolumn{2}{c}{ Sesudah Penyuluhan } \\
\cline { 2 - 5 } & Jumlah & $\mathbf{\%}$ & Jumlah & $\%$ \\
\hline Baik & 1 & 3,33 & 26 & 86,67 \\
\hline Cukup & 15 & 50 & 4 & 13,33 \\
\hline Kurang & 14 & 46,67 & 0 & 0 \\
\hline Total & 30 & 100 & 4 & 100 \\
\hline $\begin{array}{l}\text { Hasil Wilcoxon Macth Pair Test Zhitung } \\
\text { 0,4,792 dengan nilai signifikasi } \alpha \text { sebesar }\end{array}$ \\
$\begin{array}{l}\text { perbedaan pengetahuan ibu tentang autisme pada balita usia } \\
\text { dan sesudah diberi penyuluhan. }\end{array}$
\end{tabular}

Berdasarkan hasil uji statistik menggunakan Wilcoxon Match Pair Test menunjukkan hasil $\mathrm{Z}$ hitung sebesar -4,792dengan nilaisignifikasi $\alpha$ sebesar $0,000(\alpha \leq 0,05)$. Karena nilai $\alpha$ $\leq 0,05$ maka $\mathrm{H}_{1}$ diterima yang artinya ada perbedaan pengetahuan ibu tentang autisme pada balita usia 3-4 tahun sebelum dan sesudah diberi penyuluhan. 
PEMBAHASAN

Pengetahuan Ibu Tentang Autisme Pada Balita Usia 3-4 Tahun Sebelum Diberikan Penyuluhan

Berdasarkan tabel 9 diketahui bahwa pengetahuan ibu tentang autisme di Posyandu Kenanga dan Anggrek Desa Jambean, Kec. Kras, Kab. Kediri sebelum diberikan penyuluhan sebagian besar dalam kategori cukup yaitu 50\% sebanyak 15 orang. Kategori baik sebesar 3,33\% sebanyak 1 orang dan kategori kurang $46,67 \%$ sebanyak 14 orang. Dari data tersebut dapat diketahui bahwa prosentase tertinggi pada ibuterdapat dalam kategori pengetahuan cukup.

Dari hasil data khusus pengetahuan ibu sebelum penyuluhan seluruh responden yaitu ibu yang memiliki balita usia 3-4 tahun di Posyandu Kenanga dan Anggrek Desa Jambean, Kec. Kras, Kab. Kediri melalui hasil pembagian kuesioner pada 30 responden dengan jumlah soal 20 butir pada salah satu kuesioner yaitu kuesioner nomor 3.Dalam soal yang bersifat negatif tersebut menyatakan bahwa "Autisme merupakan suatu kumpulan sindrom yang mengganggu mental".Dari 30 responden, didapatkan hasil sebesar $10 \%$ responden menjawab benar.Hal ini menunjukkan, bahwa ternyata seluruh responden belum mengetahui tentang pengertian autisme.

Berdasarkan data diatas diketahui mayoritas pengetahuan ibu tentang autisme sebelum diberikan penyuluhan adalah cukup yaitu $50 \%$ sebanyak 15 responden.

Pengetahuan merupakan hasil tahu dan terjadi setelah seseorang melakukan pengindraan terhadap suatu obyek tertentu. Pengindraan terjadi melalui panca indra yaitu pengelihatan, pendengaran, penciuman, rasa dan raba. Sebagian besar pengetahuan manusia diperoleh melalui mata dan telinga(Notoatmodjo, 2012: 138 ).

Dengan semakin banyak responden memanfaatkan indera yang dimilikinya untuk proses belajar, maka semakin banyak pula pengetahuan yang akan diperoleh responden. Namun, terdapat kemungkinan lain yaitu setiap individu memiliki daya ingat dan daya tangkap yang berbeda-beda. Berdasarkan hal tersebut, maka dapat ditarik kesimpulan bahwa setiap individu memiliki pemahaman dengan tingkat yang berbeda-beda.Dari hasil penelitian dapat dijadikan acuan bahwa responden bisa saja menjawab pertanyaan dengan benar, didukung dengan kuesioner yang bersifat tertutup, dikarenakan banyak faktor seperti kemampuan dalam menganalisis soal, ketelitian dalam menjawab pertanyaan, sampai pada kemungkinan karena faktor keberuntungan.

Latar belakang pendidikan responden juga mempengaruhi pengetahuan. Berdasarkan tabel 2 didapatkan sebagian besar responden pendidikan terakhir adalah SMP sebanyak 14 responden $(46,67 \%)$.

Pendidikan berarti bimbingan yang diberikan seseorang terhadap perkembangan orang lain menuju ke arah cita-cita tertentu yang menentukan manusia untuk berbuat dan mengisi kehidupan untuk mencapai keselamatan dan kebahagiaan. Pendidikan diperlukan untuk mendapat informasi misalnya hal-hal yang menunjang kesehatan sehingga dapat meningkatkan kualitas hidup. (Wawan \& Dewi, 2010 : 16)

Meskipun pendidikan responden mayoritas cukup yaitu sederajat SMP tetapi pengetahuan mereka masih tergolong cukup. Hal ini dikarenakan kurang mampunya responden untuk menerima suatu materi dan juga 
pendidikan yang rendah akan menghambat perkembangan seseorang terhadap nilai- nilai yang baru diperkenalkan sehingga proses perubahan tingkah laku yang dinyatakan dalam bentuk penguasaan belum dapat diterima..

Faktor lain yang mempengaruhi pengetahuan responden adalah informasi yang diperoleh. Berdasarkan tabel 5 didapatkan bahwa sebanyak 24 responden $(80 \%)$ belum pernah mendapatkan informasi tentang autisme sebelumnya sedangkang 6 responden (20\%) sudah pernah mendapatkan informasi tentang autisme. Sumber informasi terbanyak tentang autisme diperoleh ibu dari tenaga kesehatan yaitu sejumlah 5 responden $(16,67 \%)$ dan 1 responden $(3,33 \%)$ dari tetangga.

Informasi merupakan sumber utama dalam meningkatkan pengetahuan.Hal ini sesuai dengan pendapat Notoatmodjo (2007), yaitu untuk meningkatkan pengetahuan dipengaruhi oleh beberapa faktor pemberian informasi.

Sumber informasi dapat mempengaruhi pengetahuan responden yang bisa dikarenakan kurang aktifnya responden dalam mencari informasi yang diperlukan, selain itu kurangnya pengalaman ibu dan daya tangkap responden yang menerima informasi juga dapat mempengaruhi. Pemberian informasi dapat dilakukan dengan berbagai macam alat bantu seperti media cetak (Koran, majalah, leaflet), media elektronik (internet, televisi, dan radio), informasi dari teman, saudara dan tetangga serta penyuluhan oleh tenaga kesehatan. Kecanggihan media masa saat ini banyak memberikan manfaat apabila digunakan dengan baik.
Pengetahuan Ibu tentang Autisme Pada Balita Usia 3-4 tahun Sesudah Diberikan Penyuluhan

Berdasarkan penelitian yang telah dilakukan didapatkan bahwa pengetahuan ibu tentang autisme pada balita usia 3-4 tahun setelah diberikan penyuluhan yaitu sebanyak 26 responden $(86,67 \%)$ dalam kategori baik dan sebanyak 4 responden $(13,33 \%)$ dalam kategori cukup, sedangkan dengan pengetahuan kurang tidak ada $(0 \%)$. Hal ini membuktikan bahwa secara umum terdapat peningkatan pengetahuan ibu tentang autisme pada balita usia 3-4 tahun setelah diberikan penyuluhan.

Dari hasil data khusus pengetahuan ibu sesudah diberi penyuluhan pada seluruh responden yaitu besar ibu yang memiliki balita usia 3-4 tahun di Posyandu Kenanga dan Anggrek Desa Jambean, Kec. Kras, Kab. Kediri melalui hasil pembagian kuesioner pada 30 responden dengan jumlah soal 20 butirpada kuesioner nomor 1. Dalam soal tersebut menyatakan bahwa "Autis adalah gangguan perkembangan yang luas dan berat yang gejalanya mulai tampak pada anak sebelum mencapai usia 3 tahun".Dari 30 responden, didapatkan hasil sebesar $100 \%$ responden menjawab benar. Hal ini menunjukkan, bahwa ternyata seluruh responden setelah diberikan penyuluhan dapat mengetahui tentang pengertian autisme.

Dari data diatas dapat diketahui bahwa pengetahuan ibu tentang autisme pada balita usia 3-4 setelah diberikan penyuluhan mayoritas dalam kategori baik yaitu sebanyak 26 responden $(86,67 \%)$.

Penyuluhan kesehatan adalah kegiatan pendidikan kesehatan, yang dilakukan dengan menyebarkan pesan, menanamkan keyakinan, sehingga masyarakat tidak saja sadar, tahu, 
mengerti, tetapi juga mau dan bisa melakukan suatu anjuran yang ada hubungannya dengan kesehatan (Machfoedz \& Suryani, 2006: 15).

Pengetahuan yang baik setelah diberi penyuluhan menunjukkan bahwa responden mampu mengingat suatu materi yang telah diterima sebelumnya, yang artinya mengingat kembali terhadap sesuatu yang spesifik dari seluruh materi yang telah diterima sebelumnya atau rangsangan yang telah diterima (Notoatmodjo, 2007 : 57).

Pengetahuan yang baik pada ibu tentang autisme pada balita usia 3-4 tahun setelah diberikan penyuluhan menunjukkan keberhasilan peneliti dalam memberikan penyuluhan. Hal ini menunjukkan bahwa informasi yang disampaikan dapat diterima dengan baik oleh responden, sehingga responden mampu menelaah dan mengerti dengan benar tentang materi yang diberikan oleh penyuluh.

Faktor yang turut berpengaruh dalam pengetahuan responden yang cukup salah satunya adalah usia. Khususnya pada usia ibu yang masih muda. Berdasarkan tabel 1 menunjukkan bahwa mayoritas responden berusia diantara 31-40 tahun sebanyak 18 responden $(60 \%)$.

Usia adalah umur individu yang terhitung mulai saat dilahirkan sampai berulang tahun. Semakin cukup umur, tingkah kematangan dan kekuatan seseorang akan lebih matang dalam berfikir maupun bekerja. Dari segi kepercayaan masyarakat, seseorang yang lebih dewasa akan lebih dipercaya dari orang yang belum cukup tinggi kedewasaannya.

(Wawan dan Dewi, 2010 : 17).

Usia seseorang mempengaruhi pengetahuan. Usia muda lebih baik dari pada usia tua. Semakin cukup umur tingkat kematangan dan kekuatan seseorangakan lebih matang dalam berfikir. Dari segi kepercayaan masyarakat yang lebih dewasa akan lebih dipercayai orang yang belum cukup kedewasaannya. Tetapi juga ada orang yang beranggapan semakin tua umur, pengetahuan seseorang semakin menurun. Dari fakta diatas mayoritas usia ibu adalah 31-40 tahun dan pengetahuan ibu juga kurang tentang autisme. Hal ini disebabkan karena kurangnya sosialisasi dari responden di lingkungan sekitar sehingga ibu kurang mendapatkan pengetahuan.Namun setelah diberikan penyuluhan pengetahuan ibu meningkat menjadi kategori baik.

Berdasarkan tabel 3 mayoritas pekerjaan ibu adalah IRT dengan jumlah 27 orang $(90,01 \%)$ dari total jumlah responden 30 orang.

Pekerjaan adalah kewajiban yang harus dilakukan terutama untuk menunjang kehidupannya dan kehidupan keluarga. Pekerjaan bukanlah sumber kesenangan, tetapi lebih banyak merupakan cara mencari nafkah yang membosankan, berulang dan banyak tantangan. Sedangkan bekerja umunya merupakan kegiatan yang menyita waktu. Bekerja bagi ibuibu akan mempunyai pengaruh terhadap kehidupan keluarga. ( Wawan\& Dewi, 2010 : 16)

Pekerjaan juga merupakan faktor yang mempengaruhi pengetahuan seseorang.Dengan bekerja seseorang dapat mengenal situasi sosial yang berbeda-beda, berhadapan dengan individu yang berbeda pula, serta mempunyai banyak akses dalam memperoleh informasi dan pengalaman baru. Pada fakta diatas mayoritas pekerjaan ibu adalah IRT sehingga dalam proses penyuluhan sebagian besar responden dapat mengikutinya ,dengan demikian penyuluhan dapat berhasil secara maksimal dalam 
memberikan pengetahuan ibu tentang autisme.

Perbedaan Pengetahuan Ibu Tentang Autisme Pada Balita Usia 34 Tahun Sebelum dan Sesudah Diberikan Penyuluhan

Berdasarkan hasil uji statistik menggunakan Wilcoxon Match Pair Testpada 30 responden menunjukkan hasil $\mathrm{Z}$ hitung sebesar -4,792dengan nilaisignifikasi $\alpha$ sebesar $0,000(\alpha \leq$ $0,05)$. Karena nilai $\alpha \leq 0,05$, maka $\mathrm{H}_{1}$ diterima yang artinya ada perbedaan pengetahuan ibu tentang autisme pada balita usia 3-4 tahun sebelum dan sesudah diberi penyuluhan.

Adanya perbedaan pengetahuan ibu tentang autisme yang ditunjang oleh data khusus. Peningkatan yang signifikan yaitu dapat dilihat dari pengetahuan sebelum dan setelah diberikan penyuluhan yaitu dari 1 responden $(3,33 \%)$ menjadi 26 responden $\quad(86,67 \%) \quad$ yang berpengetahuan baik. Dari15 responden $(50 \%)$ yang mempunyai pengetahuan cukup menjadi 4 responden $(13,33 \%)$. Sedangkan yang mempunyai pengetahuan kurang dari 14 responden $(46,67 \%)$ menjadi 0 responden $(0 \%)$.

Perbedaan pengetahuan yang tampak signifikan setelah diberikan penyuluhan memperlihatkan bahwa responden mampu menelaah dan menangkap informasi yang disampaikan melalui penyuluhan.

Menurut Wawan dan Dewi (2010 : 16-17), pengetahuan dapat dipengaruhi oleh dua faktor, yaitu faktor internal dan eksternal. Faktor internal adalah faktor dari dalam sepertiusia, pendidikan dan pekerjaan. Sedangkan faktor eksternal adalah faktor dari luar seperti lingkungan dan sosial budaya.
Pengetahuan yang baik setelah diberi penyuluhan menunjukkan bahwa responden mampu mengingat suatu materi yang telah diterima sebelumnya, yang artinya mengingat kembali terhadap sesuatu yang spesifik dari seluruh materi yang telah diterima sebelumnya atau rangsangan yang telah diterima. (Notoatmodjo, 2007:57)

Adanya penyuluhan dapat membantu para ibu yang belum mendapatkan informasi menjadi tahu dan mengerti.Pengetahuan yang baik setelah diberi penyuluhan menunjukkan bahwa responden mampu mengingat suatu materi yang telah diterima sebelumnya, yang artinya mengingat kembali terhadap sesuatu yang spesifik dari seluruh materi yang telah diterima sebelumnya atau rangsangan yang telah diterima.

\section{SIMPULAN}

1. Pengetahuan ibu tentang autisme pada balita usia 3-4 tahun sebelum diberikan penyuluhan dengan mayoritas dalam kategori cukup sebanyak 15 responden (50\%).

2. Pengetahuan ibu tentang autisme pada balita usia 3-4 tahun sesudah diberikan penyuluhan dalam kategori baik sebanyak 26 responden $(86,67 \%)$.

3. Dari analisa statistik dengan menggunakan Wilcoxon Match Pair Test menunjukkan hasil $\mathrm{Z}$ hitung sebesar $-4,792$ dengan tingkat signifikasi $\alpha$ sebesar $0,000 \quad(\alpha \leq$ $0,05)$. Karena nilai $\alpha \leq 0,05$ maka $\mathrm{H}_{1}$ diterima yang berarti ada perbedaan penegtahuan ibu tentang autisme pada balita usia 3-4 tahun sebelum dan sesudah diberi penyuluhan. 


\section{DAFTAR PUSTAKA}

Arikunto, Suharsimi. 2010. Prosedur Penelitian. Jakarta: Rineka Cipta

Bowden, Jan. 2011. Promosi Kesehatan Dalam Kebidanan. Jakarta: EGC.

Dariyo, Agoes. 2007. Psikologi Perkembangan Anak Tiga Tahun Pertama. Bandung: PT. Refika Aditama

Ginanjar, Adriana S. 2008. Menjadi Orang Tua Istimewa. Jakarta: Dian Rakyat.

Hidayat, Aziz Alimul. 2012. Riset Keperawatan dan Tehnik Penulisan Ilmiah. Jakarta: Salemba Medika.

Kementerian Kesehatan RI. 2012. Pedoman Pelaksanaan Stimulasi, Deteksi Dan Intervensi Dini Tumbuh Kembang Anak Ditingkat Pelayanan Kesehatan Dasar. Jakarta:Departemen Kesehatan RI.

Machfoedz, Ircham,. Eko Suryani. 2006. Pendidikan Kesehatan Bagian Dari Promosi Kesehatan. Yogyakarta: Fitramaya.

Maulana, Heri. 2012. Promosi Kesehatan. Jakarta: EGC.

Maulana, Mirza. 2012. Anak Autis. Yogyakarta: Kata Hati.

Notoatmodjo.Soekidjo.2007. Promosi Kesehatan dan Perilaku Kesehatan. Jakarta: Rineka Cipta.

Nursalam. 2013. Metodologi Penelian Ilmu Keperawatan. Jakarta: Salemba Medika.

Prasetyono. 2008. Serba-Serbi Anak Autis. Yogyakarta: DIVA Press.

Priyatna, Andri. 2010. Amazing Autism. Jakarta: PT. Elex Media Komputindo.
Septiari, Bety Bea. 2012. Mencetak Balita Cerdas dan Pola Asuh Orang Tua. Yogyakarta: Nuha Medika.

Setiadi. 2007. Konsep dan Penulisan Riset Keperawatan. Yogyakarta: Graha Ilmu.

Sudrajat, Dodo. Lilis, R. 2013. Pendidikan Bina Diri Anak Berkebutuhan Khusus. Jakarta: PT. Luxima.

Sugiyono, 2012.Statistika Untuk Penelitian. Bandung: Alfabeta.

Wawan, A. Dewi, M. 2010. Teori dan Pengukuran Pengetahuan, Sikap dan Perilaku Manusia. Yogyakarta: Nuha Medika.

Aniswati Syahrir. 2012. Laju Perkembangan Autisme. Diakses dari: http://m.tempo.co/read/news/2012/07/ 18060417730/Laju-PerkembanganAutisme [Diakses Tanggal 16 April 2016]

Ernie, Fitria Nur. 2012. Hubungan Pengetahuan dan Sikap Orang Tua Tentang Autisme dengan Tingkat stress Orang Tua. Diakses dari: http://www.google.com/url?sa=t\&rct=j $\& \mathrm{q}=\&$ esrc $=\mathrm{s} \&$ source $=$ web $\& \mathrm{~cd}=3 \& \mathrm{ca}$ $\mathrm{d}=$ rja\&uact $=8 \& v e d=0$ ahUKEwjMtdL7 5s7MAhXGtpQKHaVvARkQFggyM AI\&url=http $\% 3 \mathrm{~A} \% 2 \mathrm{~F} \% 2$ Fopac.say.ac id $\% 2$ F $816 \% 2$ F $1 \% 2 F N A S K A H \% 2520$ PUBLIKASI FITRIA \%2520NUR \% 25 20ERNIE 080201112.pdf\&usg=AFQj CNFkiKHxGX48VFwLjohXmj266VlWg/Hubungan-Pengetahuandan-Sikap-Orang-Tua-TentangAutisme-dengan-Tingkat-stressOrang-Tua [diakses Tanggal 10 Mei 2016]

Sukesi, Niken. Dkk. 2011. Manajemen Penatalaksanaan Deteksi Dini Tumbuh Kembang Anak Di Posyandu. Diakses 
Aprilia Nurtika Sari;Perbedaan Pengetahuan Ibu tentang Autisme Pada Balita Usia 3-4 Tahun Sebelum dan Sesudah diberi Penyuluhan

dari:

http://jurnal.unimus.ac.id/index.php/ps n12012010/article/view/1272/132/man
ajemen-Penatalaksanaan-Deteksi-DiniTumbuh-Kembang-Anak-Di-Posyandu [diakses Tanggal 10 Mei 2016] 